\title{
Selected cryopreservatives for long term storage of Helicobacter pylori at low temperatures
}

\author{
M Shahamat, C Paszko-Kolva, U E H Mai, H Yamamoto, R R Colwell
}

\begin{abstract}
To meet the need for information on cryopreservation, a study was done on 32 Helicobacter pylori strains, comparing different cryopreservative media. Sheep blood, horse blood, horse serum with and without glycerol, and mineral oil media were used for long term storage of $H$ pylori at $-70^{\circ} \mathrm{C}$ or in liquid nitrogen. Procedures were developed which permitted recovery of $87.5 \%$ of the strains included in the study after they had been stored for 24 months. Of those strains stored for more than three years, $60 \%$ were recovered. It is concluded that most strains of $H$ pylori can be stored for up to one year or longer, under refrigeration, at $-70^{\circ} \mathrm{C}$ or in liquid nitrogen.
\end{abstract}

Helicobacter pylori has an important role in the pathogenesis of chronic active gastritis type $B$ and peptic ulceration in the upper gastrointestinal tract. ${ }^{1}$ Studies of this micro-organism worldwide depend on the availability of pure, stable cultures of $H$ pylori, especially those from intestinal biopsy specimens taken during clinical investigations. Such strains must be preserved for long intervals, using reliable and reproducible methods to avoid phenotypic or genetic variation or loss. Freezedrying of Helicobacter pylori cannot be relied on to produce good recovery after subculture on solid media. ${ }^{2}$ Furthermore, not every laboratory can afford equipment to freeze-dry $H$ pylori directly from the liquid state. ${ }^{3}$ Several freezing methods for long term storage of $H$ pylori, using different cryoprotectants, have been described, ${ }^{2-8}$ but a standard method for the preservation of $H$ pylori is not available. We therefore undertook a study to compare cryoprotectants and evaluate critical technical steps in the cryopreservation of $H$ pylori.

\section{Methods}

Department of

Microbiology,

University of

Maryland, College

Park, Maryland 20742,

USA

M Shahamat

C Paszko-Kolva

U E H Mai

H Yamamoto

R R Colwell

Correspondence to:

Dr R R Colwell

Accepted for publication

15 January 1992
A total of $32 \mathrm{H}$ pylori strains (table 1) were obtained from the National Collection of Type Cultures (NCTC). Before cryopreservation, cultures were grown on freshly prepared blood agar base No 2 (Oxoid), modified with $8 \%$ defibrinated horse blood, for 72 hours under microaerobic, humidified conditions at $37^{\circ} \mathrm{C}$. Helicobacter pylori cells were harvested by scraping growth from the solid medium with a sterile spatula and resuspending the cells directly in cryoprotective media. The harvested cells were adjusted to concentrations of $10^{\circ}$ to
$10^{10}$ viable spiralic (non-coccoid) $H$ pylori per $\mathrm{ml}$ in cryoprotective media. Enumeration was by acridine orange direct counting (AODC). ${ }^{9}$ The cryopreservatives tested were defibrinated horse blood, defibrinated sheep blood, and horse serum (Remel, Lenexa, Kansas). The media tested consisted of one of these with and without $10 \%$ glycerol. Five strains were also tested further by the addition of $20 \mu \mathrm{l}$ of sterile mineral oil to another series of phials with horse blood. Cryophials containing $0.5 \mathrm{ml}$ of the bacterial suspension in the cryopreservative solutions were frozen immediately after inoculation at $-70^{\circ} \mathrm{C}$ and a duplicate set was placed in liquid nitrogen. At established intervals, the frozen $H$ pylori samples were thawed at room temperature. At recovery, the total number of cells was determined by AODC and recovery was measured by culturing samples on freshly prepared blood agar base No 2 (Oxoid) modified with $8 \%$ defibrinated horse blood. The recovered bacteria were confirmed as $H$ pylori by epifluorescence microscopy and Gram stain. Urease, catalase, and oxidase tests were also performed.

\section{Results and discussion}

To establish a reliable procedure for cryopreservation of $H$ pylori which can be used routinely in most microbiology laboratories,

\section{Table 1 Strains of $H$ pylori tested in this study}

\begin{tabular}{ll}
\hline Source & Collection Number \\
\hline NCTC & 31155 \\
NCTC & RSB6 \\
NCTC & 31604 \\
NCTC & 11219 \\
NCTC & 20200 \\
NCTC & 12954 \\
NCTC & 33097 \\
NCTC & A-314 \\
NCTC & 33098 \\
NCTC & 12648 \\
NCTC & 60191 \\
NCTC & 60190 \\
NCTC & $T \times 30 A$ \\
NCTC & 955 \\
NCTC & 11639 \\
NCTC & 11637 \\
NCTC & 26695 \\
NCTC & 26694 \\
NCTC & 7546 \\
NCTC & 1196 \\
NCTC & 48608 \\
NCTC & 52815 \\
NCTC & 41356 \\
NCTC & 189 \\
NCTC & 111 \\
NCTC & 99 \\
NCTC & 107 \\
NCTC & 53 \\
NCTC & 61 \\
NCTC & 110 \\
NCTC & 186 \\
\hline
\end{tabular}


Table 2 Recovery of Helicobacter pylori from horse blood after storage for 24 months at $-70^{\circ} \mathrm{C}$

\begin{tabular}{|c|c|c|c|}
\hline $\begin{array}{l}\text { No of strains } \\
\text { tested }\end{array}$ & $\begin{array}{l}\text { Length of time } \\
\text { held in storage }\end{array}$ & $\begin{array}{l}\text { Efficiency of } \\
\text { recovery }\end{array}$ & $\begin{array}{l}\text { Percentage of } \\
\text { recovered cells }\end{array}$ \\
\hline $\begin{array}{r}8 \\
15 \\
2 \\
3 \\
4\end{array}$ & 24 months & $\begin{array}{l}++++^{\star} \\
+++ \\
++ \\
+ \\
+\end{array}$ & $\begin{array}{r}25 \\
47 \\
6 \\
9 \\
13\end{array}$ \\
\hline
\end{tabular}

*Maximal cells recovered $=++++$, good growth $=+++$ moderate growth $=++$, weak growth $=+$ and no growth $=-$.

conditions necessary for successful preservation of $H$ pylori grown on solid media and using different cryopreservatives were evaluated. Horse blood and sheep blood, with and without glycerol, gave comparable results, with recovery of up to $60-80 \%$ of the original inoculum for most of the strains included in the study after storage for $\mathbf{2 4}$ months or longer. Recovery from horse serum was poor in some cases, or unsuccessful. Five of the strains of $H$ pylori, randomly selected and frozen in horse blood with $20 \mu$ l sterile mineral oil, were not recovered at all.

Recovery success for 32 of the strains tested, calculated from number of colonies on blood agar plates after incubation for three days, showed that 28 of the $32(87.5 \%)$ strains could be recovered after storage for 24 months at $-70^{\circ} \mathrm{C}$ (table 2). Strain differences in the success of recovery were observed. Eight $(25 \%)$ strains yielded full recovery, $15(47 \%)$ showed good recovery, two (6\%) moderate recovery, and three $(9 \%)$ poor recovery after storage for 24 months (table 2). Of 32 strains tested, four (13\%) could not be recovered at all. Thus some strains are more susceptible to storage conditions, regardless of the cryopreservative used.

Further analysis of the results showed that 15 of the 32 strains stored at $-70^{\circ} \mathrm{C}$ in horse blood for 44 months could be cultured and nine of $15(60 \%)$ strains could be recovered fully. On the other hand, two $(13 \%)$ strains produced only a few colonies and four (27\%) strains did not grow at all. As storage time increases, a larger number of strains lose the ability to grow on blood agar plates. A single cycle of thawing and freezing, for strains at the same storage temperature, did not reduce recovery significantly for most strains included in the study. However, when cultures were thawed and refrozen at a higher temperature $\left(-20^{\circ} \mathrm{C}\right)$, most of the strains did not grow on blood agar plates under the same conditions as described above. Previous reports indicate that $H$ pylori cannot be recovered even after one month if cell suspensions are transferred directly from plates to glycerol or glycerol plus fetal bovine serum. ${ }^{3}$ The results obtained suggest that transferring $H$ pylori directly from solid medium into blood will result, in most cases, in the bacteria being preserved for up to
44 months. However, storage in horse serum alone was not sufficient to preserve $H$ pylori for the same period of time. According to published data, $H$ pylori can be stored in Brucella broth in liquid nitrogen, but the length of the storage time was not reported nor was the efficiency of recovery. ${ }^{8}$ Westblom et al recovered $H$ pylori from horse blood stored at $-70^{\circ} \mathrm{C}$ for six months. In the study reported here we recultured organisms after storage for 24 and 44 months at $-70^{\circ} \mathrm{C}$, with most of the cells viable and able to be cultured without difficulty.

In conclusion, criteria recommended for preservation and long term storage of $H$ pylori are as follows. The initial inoculum should be larger than $5 \times 10^{9}$ cells $/ \mathrm{ml}$, and at least $90 \%$ of the cells should be vegetative, spiral-shaped cells when stained directly by AODC. Underlying this recommendation is our observation that coccoid forms readily arise in $H$ pylori cultures when microenvironmental conditions are unfavourable for growth and the coccoid cells cannot be recultured easily, if at all, on solid media, using standard bacteriological culture methods (personal observations). ${ }^{10} \mathrm{~A}$ storage temperature of $-70^{\circ} \mathrm{C}$ is sufficient to provide a shelf-life of two years or more. Addition of glycerol to avoid ice crystal formation during the freezing process and, consequently, destruction of internal structures of the bacteria, will be less of a problem if the medium contains a high concentration of serum. Strain differences in response to these conditions, despite their being optimal for frozen storage, can be expected.

In any case, the conditions suggested above should permit successful frozen storage for most strains of $H$ pylori, an important consideration when doing research on this fascinating, but often difficult (to culture) bacterium.

1 Blaser MJ. Helicobacter pylori and the pathogenesis of gastroduodenal inflammation. F Infect Dis 1990;161: 626-33.

2 Buck GE, Smith JS. Medium supplementation for growth of Campylobacter pyloridis. $\mathcal{f}$ Clin Microbiol 1987;25: 597-9.

3 Drumm B, Sherman P. Long term storage of Campylobacter pylori. $\mathcal{F}$ Clin Microbiol 1989;27:1655-6.

4 Goodwin CS, Armstrong JA. Microbiological aspects of Helicobacter pylori (Campylobacter pylori) Eur $\mathcal{f}$ Clin Microbiol Infect Dis 1990;9:1-13.

5 Hobbie JE, Daley RJ, Jasper S. Use of nucleopore filters for counting bacteria by fluorescence microscopy. Appl Environ Microbiol 1977;33:1225-8.

6 Langenberg W, Rauws EAJ, Widjojokusumo A, Tytgat GNJ, Zanen HC. Identification of Campylobacter pyloridis isolates by restriction endonuclease DNA analysis. $\mathcal{f}$ Clin Microbiol 1986;24:414-7.

7 Mai U, Geis G, Leying H, Ruhl G, Opferkuch W. Diomorphism of Campylobacter pylori, In: Megraud F, Lamouliatte H, eds. Gastroduodenal pathology and Campylobacter pylori. Amsterdam: Excerpta Medica, 1989: 29-33.

8 Queiroz DMM, Mendes EN, Rocha GA. Indicator medium for isolation of Campylobacter pylori. $\exists$ Clin Microbiol 1987;25:2378-9.

9 Ribeiro CD, Gray SJ. Long term storage of Campylobacter pyloridis. F Clin Pathol 1987;40:1265.

10 Westblom TU, Barthel JS, Havey AD, Gonzalex FJ, Tarka EF, Everett ED. Long term freeze storage of Campylobacter pyloridis. F Clin Pathol 1987;40:353. 